\title{
PERSEPSI MASYARAKAT LOKAL TERHADAP PENGEMBANGAN DESA WISATA BERBASIS ADAT
}

\author{
Andri Sulistyani ${ }^{1}$, Rd. Siti Sofro Sidiql ${ }^{2}$, dan Chelsy Yesicha ${ }^{3}$ \\ ${ }^{1}$ Jurusan Ilmu Administrasi, FISIP Universitas Riau Pekanbaru \\ ${ }^{2}$ Jurusan Sosiologi, FISIP Universitas Riau Pekanbaru \\ ${ }^{3}$ Jurusan Ilmu Komunikasi, FISIP Universitas Riau Pekanbaru
}

\begin{abstract}
Culture-based tourism village has become one of the trends in developing populist tourism. This sudy aims to measure the perception of the local community towards the development of indigenous village tourism based on Kenegerian Sentajo. The measured variableswere included perceptions of the local community towards the foreigners, the attractions, amenities, and accessibilities. The result showed that the community agreed that tourism activities was carried out as an effort to improve the economy by a score range of $80.21 \%-100 \%$. However, in terms of indicators of the local community openness to the foreigner and outsider investors, they made an implicit rejection by a score range of $44.04 \%$ until $79.36 \%$. For this reason, a study on tourism development using an ethno-ecological approach and training supports were strongly recommended as a following action.

Abstrak: Desa wisata berbasis budaya menjadi salah satu trend pengembangan wisata kerakyatan. penelitian ini bertujuan untuk mengukur persepsi masyarakat lokal terhadap pengembangan desa wisata berbasis adat kenegerian Sentajo. Variabel diukur meliputi persepsi terhadap wisatawan, atraksi, amenitas, aksesibilitas. Hasil menunjukkan bahwa masyarakat menyetujui pembangunan pariwisata dilaksanakan sebagai salah satu upaya peningkatan perekonomian dengan rentang skor $80,21 \%-100 \%$. akan tetapi, dalam indikator keterbukaan terhadap orang asing dan investor luar, mereka melakukan penolakan secara implisit dengan rentang skor 44,04\%-79,36\%. Untuk itu, kajian pembangunan pariwisata dengan pendekatan etno-ekologi dan dukungan pelatihan sangat disarankan sebagai tindak lanjutnya.
\end{abstract}

Kata kunci: desa wisata berbasis adat, persepsi, Kenegerian Sentajo

\section{PENDAHULUAN}

Target Pemerintah Indonesia untuk memeratakan hasil pembangunan dan kesejahteraan masyarakat yang berkeadilan sosial menuntut peran aktif segala pemangku kepentingan. Struktur penggerak pembangunan bersistem pentahelix membutuhkan peran serta dari pemerintah sebagai fasilitator, akademisi sebagai insiator pemberi arahan dan rekomendasi, praktisi bisnis sebagai aktor, masyarakat sebagai eksekutor, dan media massa sebagai faktor pendukung pembangunan di era digital ini.

Tingginya pendapatan negara dari sektor pariwisata ini tentunya didukung oleh kenaikan wisatawan mancanegara yang ditargetkan sebesar 17 juta di tahun 2018 (Handoko, 2018). Sejalan dengan hal tersebut, Kementerian Pariwisata Republik Indonesia telah menetapkan bahwa tiga (3) top prioritas pembangunan kepariwisataan diarahkan pada pembangunan digital tourism, homstay dan desa wisata, serta jejaring airlines (transportasi udara). Demikian pula hal yang dilakukan oleh Pemerintah Provinsi Riau melalui Dinas Pariwisata Provinsi yang turut menetapkan desa wisata dan homestay sebagai top ptioritas kedua pembangunan pariwisata Riau, disamping peluncuran digital tourism dan aksesibilitas yang perlu terus dibenahi.

Salah satu wilayah yang potensial untuk dikembangkan menjadi desa wisata dengan keunikan khusus adalah Koto Sentajo. Wilayah ini merupakan salah satu kawasan adat yang telah dinobatkan sebagai desa cagar budaya dan sekaligus telah dikukuhkan sebagai desa wisata oleh Pemerintah Kabupaten Kuantan Singingi. Secara administratif, desa Koto Sentajo terletak di Kecamatan Sentajo Raya, Kabupaten Kuantan Singingi, Provinsi Riau. Lokasinya berjarak sekitar 3-4 jam dari pusat kota Pekanbaru. Kabupaten Kuantan Singingi sangat lekat dengan salah satu event pariwisata nasional tahunan, yaitu Pacu Jalur di Batang Kuantan. Wilayah ini 
mudah dijangkau dengan akses tranportasi darat yang bagus. Segala bentuk keunggulan atraksi alam dan budaya yang sifatnya ajeg, aksesibilitas, dan ketersediaan amenitas ini tentunya membuat wilayah ini patut dilirik sebagai salah satu destinasi unggulan di Provinsi Riau.

Penetapan desa wisata dan homestay sebagai skala prioritas tentunya diambil dengan berbagai pertimbangan. Desa wisata merupakan bentuk penampilan wajah pariwisata yang asli. Masyarakat desa yang santun dan ramah dapat menjadi ujung tombak pelayanan wisatawan yang murah dan alamiah. Selain itu, jika tujuan pembangunan pariwisata bukanlah untuk konglomerasi, maka berkumpulnya transaksi antara wisatawan dengan penyedia jasa layanan di desa akan mampu mewujudkan pariwisata berkesejahteraan (Nuryanti, 1999).

Untuk itu, sejalan dengan arahan pembangunan Pemerintah Negara Indonesia secara umum, dan Pemerintah Provinsi Riau khususnya, peneliti berasumsi bahwa penelitian mengenai persepsi masyarakat lokal Koto Sentajo terhadap pengembangan desa wisata berbasis adat ini sangat perlu untuk dilaksanakan. Selain akan mampu menggali potensi atraksi wisata, penggalian terhadap persepsi masyarakat akan memberikan gambaran kesediaan dan kesiapan masyarakat untuk menerima kedatangan wisatawan, memamerkan atraksi wisata adat dan budaya yang dimilikinya, serta menjamu orang di luar adatnya yang ikut menikmati sajian wisata di wilayahnya.

Persepsi secara umum digunakan sebagai istilah dalam ilmu psikologi. Asrori (2009) menjelaskan persepsi sebagai proses individu dalam menginterpretasikan, mengorganisasikan, dan memberi maknaterhadap stimulus yang berasal dari lingkungan di mana individu itu berada yang merupakan hasil dari proses belajar dan pengalaman. Dalam hal ini, persepsi dipengaruhi oleh dua hal pokok, yaitu interpretasi dan pengorganisasian informasi yang diserap oleh manusia.

Slameto (2010) mengungkapkan jika melalui persepsilah manusia terus-menerus berkaitan dengan lingkungannya. Hubungan ini dilakukan melalui indera penglihatan, pendengar, peraba, perasa, dan pencium. Selanjutnya, untuk membentuk sebuah persepsi, terdapat syarat-syarat yang harus dipenuhi, yaitu (Walgito, 1989): 1)Adanya objek yang diinterpretasi; 2) adanya alat indera/reseptor; dan 3) adanya perhatian.

Selanjutnya, persepsi akan dipengaruhi banyak faktor, terutama faktor psikologis yang dimiliki individu pelaku persepsi. Prosesnya terjadi dalam beberapa tahapan (Walgito, 1989), yaitu: 1) penerimaan rangsangan dari objek oleh indera/reseptor (proses kealaman/fisik); 2) rangsangan diteruskan ke otak oleh syaraf sensoris (proses fisiologis); 3) rangsangan diolah oleh otak, diinterpretasi, dan diberikan respon/reaksi di mana individu menjadi menyadari tentang apa yang diterimanya (proses psikologis).

Terdapat beberapa faktor yang mempengaruhi persepsi. Toha (2003) menyatakan bahwa persepsi dipengaruhi oleh: 1) faktor interal individu berupa perasaan, sikap, kepribadian, keinginan, prasangka, harapan, perhatian, proses belajar, keadaan fisik, gangguan kejiwaan, nilai, kebutuhan, minat, motivasi; dan 2) faktor eksternal, berupa latar belakang keluarga, informasi yang diperoleh, pengetahuan dan kebutuhan sekitar, intensitas, ukuran, keberlawanan, pengulangan gerak, hal-hal baru dan ketidak asingan terhadap objek. Adapun Krech (dalam Robbins, 1996), menjelaskan bahwa terdapat 2 sisi dalam melakukan persepsi. Kedua sisi (frame) tersebut adalah: 1) Frame of reference, yaitu kerangka pengetahuan yang dimilikiyang dipengaruhi oleh bacaan, pengetahuan, pendidikan, penelitian, dan sejenisnya; dan 2) frame of experience, yaitu pengalaman yang telah dialami individu dan tidak terlepas dari keadaan lingkungan sekitarnya.

Desa wisata secara umum merupakan sebentuk kawasan yang menawarkan suasana asli pedesaan. Kehidupan sosial budaya, sosial ekonomi, adat istiadat, rutinitas sehari-hari, arsitektur bangunan, landskap pemukiman yang khas merupakan daya tarik bagi wisatawan. Secara khusus, Nuryanti (1993) menyatakan bahwa desa wisata merupakan bentuk integrasi antara atraksi, akomodasi, fasilitas pendukung yang disajikan dalam suatu struktur kehidupan masyarakat yang menyatu dengan tata cara dan 
tradisi yang berlaku. Dengan demikian, unsur desa wisata harus meliputi manusia, ruang, dan waktu yang membentuk keselarasan ekosistem di dalamnya.

Menurut Dermatoto (2009:), desa wisata merupakan sebuah kawasan pedesaan yang memiliki beberapa karakteristik khusus untuk menjadi daerah tujuan wisata. Kawasan ini merupakan kesatuan antara manusia dengan alam dan tradisi serta budaya yang masih asli. Dukungan daya tarik tambahan dapat berupa ragam kuliner khas, sistem sosial, adat, dan kemasyarakatan, sistem pertanian, serta ragam hasil bumi dan bentang alam.

Wisata pedesaan menawarkan daya tarik wisata alami secara menyeluruh. Keaslian kehidupan pedesaan ditampilkan dengan menonjolkan kehidupan ekonomi, sosial, dan adat istiadat mesyarakat setempat, arsitektur bangunan desa, dan kuliner tempatan. Hal ini akan berdampak pada pengalaman berwisata bagi wisatawan yang benar-benar berbeda dari kehidupan kesehariannya. Terkait kegiatan ini, desa wisata dituntut untuk dapat menyediakan atraksi yang menarik dan variatif. Aksesibilitas kawasan juga harus mudah dijangkau dengan kendaraan umum dan pribadi dan murah dalam pembiayaannya. Demikian pula dengan fasilitas amenitas untuk mendukung kenyamanan wisatawan selama berada di dalam kawasan, seperti sarana sanitasi, fasilitas makan minum, ATM/perbankan, dan fasiltas tinggal wisatawan (homestay, hotel). Penentuan titik lokasi kegiatan pariwisata, harga jual, dan persebaran pendapatan masyarakat dari hasil kegiatan pariwisata harus mampu mengakomodasi kebutuhan wisatawan dan masyarakat lokal secara adil. Terlebih karakteristik wisatawan jenis ini kebanyakan menghabiskan waktu lama di dalam kawasan, berkelompok kecil maupun perorangan, kebutuhan akan pengalaman baru, serta jumlah pengeluaran wisatawan yang relatif lebih besar dari jenis kegiatan wisata lainnya.

\section{METODE}

Penelitian ini menggunakan metode descriptive exploratory, yaitu dengan membuat gambaran mengenai situasi atau fenomena yang dimaksudkan untuk causal-predictive analysis (Ghozali, 2011). Nazir (2011) menyatakan bahwa metode ini dapat digunakan untuk menerangkan hubungan, menguji hipotesis, membuat prediksi, serta mendapatkan makna implisit dari suatu masalah yang ingin dipecahkan.

Populasi dalam penelitian ini adalah 1514 jiwa. Adapun untuk mengukur persepsi diperlukan teknik sampling proporsional stratified random sampling untuk menemukan sasaran responden yang tepat. Jumlah sampel yang diambil adalah 94 orang yang diperoleh dari penghitungan rumus slovin. Adapun instrumen penelitian ini menggunakan teknik skala likert (summated rating scale) di mana setiap pernyataan yang telah ditulis dapat disepakati sebagai pernyataan favourable atau pernyataan unfavourable, dan subjek menanggapi setiap butir pernyataan dengan menggunakan taraf (intensitas) Sangat Setuju-Sangat Tidak Setuju terhadap pernyataanpernyataan yang tersedia. Selanjutnya, skor-skor tersebut dijumlahkan. Dalam skala Likert, terdapat dua jenis pernyataan, yakni pernyataan positif dan pernyataan negatif, di mana untuk pernyataan postif dengan jawaban "Sangat Setuju" memeperoleh nilai 5 dan untuk jawaban "Sangat Tidak Setuju" memperoleh angka 1.

Tabel 1. Indikator Penelitian

\begin{tabular}{|c|c|c|}
\hline Variabel & \multicolumn{2}{|r|}{ Indikator } \\
\hline \multirow[t]{4}{*}{$\begin{array}{l}\text { Persepsi } \\
\text { masyarakat } \\
\text { lokal }\end{array}$} & Wisatawan & $\begin{array}{l}\text { 1. Daerah asal wisatawan } \\
\text { 2. Warna kulit } \\
\text { 3. Budaya asal } \\
\text { 4. Agama } \\
\end{array}$ \\
\hline & Atraksi & $\begin{array}{ll}\text { 1. } & \text { Budaya sehari-hari } \\
\text { 2. } & \text { Pacu jalur } \\
\text { 3. } & \text { Randai } \\
\text { 4. } & \text { Bangunan bersejarah } \\
\end{array}$ \\
\hline & Amenitas & $\begin{array}{l}\text { 1. Dibukanya kedai makan minum } \\
\text { 2. Kebersihan lingkungan/ Toilet umum/IPAL } \\
\text { 3. Rumah godang sebagai homestay } \\
\text { 4. Jenis makanan dan minuman yang disediakan }\end{array}$ \\
\hline & Aksesibilitas & $\begin{array}{l}\text { 1. Keterbukaan pribadi masyarakat } \\
\text { 2. Ketersediaan jalan lingkungan } \\
\text { 3. Ketersediaan angkutan } \\
\text { 4. } \\
\end{array}$ \\
\hline
\end{tabular}

Metode yang di gunakan untuk mengukur persepsi masyarakat adalah Metode Skala Likert. Skala Likert merupakan metode pengukuran yang digunakan untuk mengukur sikap, pendapat, dan persepsi seseorang atau kelompok orang tentang fenomena sosial (Sugiono, 2012). Sedangkan menurut Dane Bertram pada jurnalnya "Likert Scale" (http://www.rolahengki. com/2013) menjelaskan bahwa skala respon psikometri terutama digunakan dalam kuesioner 
untuk mendapatkan preferensi peserta atau tingkat kesepakatan dengan pernyataan atau setelah pernyataan. Skala Likert adalah teknik skala non komparatif dan undimensional (hanya mengukur sifat tunggal) secara alami. Responden diminta untuk menunjukkan tingkat kesepakatan melalui pernyataan yang diberikan dengan skala ordinal. Dari dua pengertian diatas kita sudah bisa menyimpulkan bahwa skala likert merupakan metode perhitungan kuisioner yang dibagikan kepada responden untuk mengetahui skala sikap suatu objek tertentu.

\section{HASIL DAN PEMBAHASAN}

Menurut Suansri dalam REST Project (2003), proses pelibatan masyarakat dalam pengembangan kepariwisataan disebut dalam banyak terminologi, seperti community based tourism (CBT), community based ecotourism (CBET), Agrotourism, Eco and Adventure Tourism dan homestay. Murphy (1985) merupakan ahli pariwisata pertama yang memperkenalkan konsep ini. CBT menurut Murphy (1985) merupakan pelibatan masyarakat secara sadar dan langsung sebagai bagian dari produk pariwisata sebagai pihak yang menghasilkan produk untuk dikonsumsi wisatawan, sekaligus sebagai pihak pertama yang terdampak langsung dari aktivitas tersebut.

Gunn (1993) telah mengkampanyekan pelaksanaan forum bersama yang melibatkan peran masyarakat, pemerintah, dan pemangku kepentingan lainnya dalam pembangunan kegiatan pariwisata. Menurutnya, konsep CBT memiliki prinsip-prinsip khusus yang wajib dipenuhi sebagai alat pembangunan komunitas lokal, meliputi: 1) adanya pengakuan, dukungan, dan promosi aset pariwisata yang dimiliki masyarakat lokal; 2) pelibatan anggota masyarakat di setiap tahap pembangunan pariwisata; 3) mempromosikan ciri khas/kebanggaan masyarakat lokal; 4) adanya peningkatan kulitas hidup masyarakat; 5) adanya jaminan kelestarian lingkungan; 6) mempertahankan karakter dan budaya lokal yang unik; 7) adanya penghormatan terhadap perbedaan budaya dan hak-hak asasi manusia; 8) mengembangan pemahaman lintas budaya (cross cultural understanding); 9) mendistribusian keuntungan secara adil kepada setiap anggota masyarakat; 10) Memberikan pendapatan optimal kepada masyarakat lokal.

Berdasarkan hal tersebut, perencanaan model pariwisata berbasis masyarakat cenderung kepada upaya mendapatkan keuntungan dengan tetap mengkonservasi keunikan karakter dan budaya masyarakat setempat, bersifat top-down management, berorietasi bisnis dengan pendekatan ekonomi yang kuat (Bahaire dalam ElliotWhite, 1999:248). Elemen-elemen CBT berupa sumber daya alam dan budaya, organisasi masyarakat, manajemen, dan pembelajaran menjadi titik tolak pelaksanaan kegiatan pariwisatadi daerah. Dengan adanya proses pembelajaran, diharapkan proses pertukaran informasi dan traksaksi antara wisatawan dengan penduduk lokal dapat berlangsung dan bermanfaat secara optimal.

Desa Koto Sentajo merupakan salah satu kawasan desa yang diusulkan sebagai kawasan cagar budaya berbasis adat di Kecamatan Sentajo Raya kabupaten Kuantan Singingi Provinsi Riau. Desa ini merupakan bagian dari Kenegerian Sentajo Bawah. Sebagaimana hasil wawancara dengan Kaur Desa Koto Sentajo, menjelaskan bahwa Kenegerian Sentajo Raya terdiri atas 14 desa dan 1 keluarahan yang tercakup dalam 3 adat kenegerian, yaitu Kenegerian Sentajo Bawah, Kenegerain Sentajo Atas, dan Kenegerian Teratak Air Hitam. Dari keseluruah desa di Kecamatan Sentajo Raya, hanya Kampung Baru Sentajo dan Beringin Jaya yang berkategori swasembada, adapaun ke-13 desa lainnya, termasuk Koto Sentajo masih berkelas swadaya (BPS, 2017). Setiap desa/kelurahan dibantu oleh prangkat desa/kelurahan, yaitu sekretaris, kaur umum, kasi pemerintahan, kasi PMD dan kepala dusun/kepala lingkungan.

Sebagai desa wisata yang diunggulkan oleh Kabupaten Kuantan Singingi, Koto Sentajo memiliki kekhasan yang terjaga baik berupa rumah godang, randai, perlombaan pacu jalur baik tingkat rayon maupun kabupaten, tradisi berkebun, merawang (mencari ikan oleh ibuibu di sungai kering), menggembala kerbau secara komunal, ragam jenis makanan tradisional, hingga tradisi perayaan raya kedua secara massal 
di tiap-tiap rumah godang. Berikut disajikan tabel potensi sosial budaya masyarakat Koto Sentajo yang dapat diangkat sebagai atraksi budaya.

Berdasarkan Tabel 2 dari keseluruhan kegiatan yang dapat dilaksanakan di Koto Sentajo tersebut, Dusun Gontiang merupakan sentral eksistensi Koto Sentajo sebagai desa wisata cagar budaya. Sebanyak 27 rumah godang milik 4 persukuan tersebar berdekatan di wilayah dusun ini.

Sebagai informasi keterbukaan masyarakat lokal terhadap pembentukan calon desa wisata, maka dilakukan survei terhadap indikatorindikator dalam pembangunan pariwisata desa, yaitu wisatawan, atraksi, amenitas, aksesibilitas. Secara rinci, rekapitulasi jawaban responden ada pada Tabel 3.

Hasil kuesioner tersebut menunjukkan bahwa masyarakat masih memandang daerah asal wisatawan sebagai salah satu tolok ukur penerimaan terhadap orang asing yang memasuki wilayah adatnya. Budaya wisatawan diminta juga akan mampu menyesuaikan dengan adat setempat, tidak memakai busana terbuka yang mencolok,bersikap sopan, dan menghargai tradisi masyarakat setempat. Selain itu, masyarakat Koto Sentajo ternyata mampu bersikap terbuka terhadap penganut agama lain meskipun ketaatan terhadap agama Islam sangat ditekankan.

Berdasarkan hasil wawancara dengan responden, mereka mengakui bahwa sangat senang jika seni tradisinya dapat dinikmati oleh wisatawan. Hanya saja, merekamasih menyiratkan keberatan jika rumah pribadi yang ditinggalinya dapat dilihat oleh orang asing. Hal ini dibuktikan dengan pernyataan bahwa orang asing boleh mengakses fasilitas dan bangunan umum seperti rumah godang kosong dan masjid Raudhatul Jannah, tetapi mereka malu jika perilaku hidup sehari-harinya menjadi bahan pengamatan. Dengan demikian, mereka tetap membutuhkan privasi yang terjaga untuk kehidupan sehari-hari.

Selanjutnya, masyarakat sangat berminat penambahan fasilitas makan dan minum ditambah dengan inisiatif ekonomi swadaya masyarakat. Mereka dapat menambah pendapatan dari kedai tersebut, hanya saja terkendala besarnya modal yang akan dikeluarkan.

Selain itu, berdasarkan hasil observasi, masyarakat masih membutuhkan banyak penyuluhan pola hidup bersih dan sehat (PHBS) dari pihak terkait. Hal ini ditunjukkan dengan masih digunakannya sungai sebagai tempat mandi, cuci, kakus (MCK) secara umum. Desa Koto Sentajo telah memiliki 1 IPAL (instalasi pengolahan air limbah) yang berada di dusun Bukit. Akan tetapi, fasilitas ini belum tersedia di dusun Gontiang, sehingga MCK permanen yang tersedia pun belum berfungsi maksimal. Hanya terdapat $1 \mathrm{MCK}$ umum permanen yang layak pakai.

Beragam makanan tradisional juga tersedia di Koto Sentajo. Salah satu makanan khasnya berupa rendang pakis yang selau disajikan di hari biasa maupun hari besar adat. Selain itu, juga tersedia kue-kue tradisional seperti

Tabel 2. Ragam Potensi Atraksi Sosial Budaya Masyarakat Koto Sentajo

\begin{tabular}{|l|l|l|l|l|l|}
\hline \multirow{2}{*}{ No } & \multicolumn{1}{|c|}{ Nama } & \multicolumn{3}{|c|}{ Rutinitas dapat ditampilkan } \\
\cline { 3 - 5 } & & \multicolumn{1}{|c|}{ Harian } & Mingguan & Bulanan & Tahunan \\
\hline 1. & Rumah Godang 28 unit & & & & \\
\hline 2. & Randai/silat pandekar bertuah & & & \\
\hline 3. & Mansojid osang & & & \\
\hline 4. & Rumah jalur & & & \\
\hline 5. & Merawang & & & \\
\hline 6. & $\begin{array}{l}\text { Menyusuri sungai kuantan untuk mencari } \\
\text { ikan atau belajar naik jalur mini }\end{array}$ & & & \\
\hline 7. & Bersawah & & & \\
\hline 8. & Menggembala ternak & & & \\
\hline 9. & $\begin{array}{l}\text { Menyusuri hutan lindung Kenegerian } \\
\text { Sentajo (ekowisata) }\end{array}$ & & & \\
\hline 10. & Belajar berkebun & & & & \\
\hline 11. & Tradisi Rayo Kedua & & & \\
\hline
\end{tabular}


Tabel 3. Rekapitulasi Persepsi Masyaraka Terhadap Pengembangan Desa Wisata Koto Sentajo

\begin{tabular}{|c|c|c|c|c|}
\hline Variabel & Indikator & Total Skor & Presentase & Kriteria Skor \\
\hline \multirow[t]{4}{*}{ Wisatawan } & $\begin{array}{l}\text { Masyarakat memperhatikan daerah } \\
\text { asal wisatawan (domestik dan luar } \\
\text { negeri) }\end{array}$ & 278 & $59,15 \%$ & Cukup setuju \\
\hline & $\begin{array}{l}\text { Masyarakat memperhatikan warna } \\
\text { kulit wisatawan sebagai } \\
\text { pertimbangan (ras dan sukunya) }\end{array}$ & 207 & $44,04 \%$ & Cukup setuju \\
\hline & $\begin{array}{l}\text { Masyarakat memperhatikan budaya } \\
\text { asal yang dibawa wisatawan }\end{array}$ & 409 & $87,02 \%$ & Sangat setuju \\
\hline & $\begin{array}{l}\text { Agama wisatawan menjadi } \\
\text { pertimbangan mengizinkan } \\
\text { di desa }\end{array}$ & 245 & $52,12 \%$ & Cukup setuju \\
\hline \multirow[t]{4}{*}{ Atraksi } & $\begin{array}{l}\text { Wisatawan boleh menyakasikan } \\
\text { budaya sehari-hari }\end{array}$ & 461 & $98.08 \%$ & Sangat setuju \\
\hline & $\begin{array}{l}\text { Pacu jalur dan adat lainnya terbuka } \\
\text { untuk wisatawan }\end{array}$ & 470 & $100 \%$ & Sangat setuju \\
\hline & $\begin{array}{l}\text { Randai boleh dimainkan untuk } \\
\text { wisatawan bila perlu }\end{array}$ & 470 & $100 \%$ & Sangat setuju \\
\hline & $\begin{array}{l}\text { Bangunan bersejarah (Rumah } \\
\text { godang, masjid osang) } \\
\text { dimasuki wisatawan }\end{array}$ & 470 & $100 \%$ & Sangat setuju \\
\hline \multirow[t]{4}{*}{ Amenitas } & Dibukanya kedai makan minum & 437 & $97,97 \%$ & Sangat setuju \\
\hline & $\begin{array}{l}\text { Kebersihan lingkungan/ } \\
\text { umum/IPAL perlu dijaga }\end{array}$ & 470 & $100 \%$ & Sangat setuju \\
\hline & $\begin{array}{l}\text { Penggunaan rumah godang sebagai } \\
\text { homestay }\end{array}$ & 426 & $90,63 \%$ & Sangat setuju \\
\hline & $\begin{array}{llr}\text { Ragam jenis makanan } & \text { dan } \\
\text { minuman tradisional yang } & \text { boleh } \\
\text { disediakan untuk wisatawan } & \\
\end{array}$ & 470 & $100 \%$ & Sangat setuju \\
\hline \multirow[t]{4}{*}{ Aksesibilitas } & $\begin{array}{l}\text { Keterbukaan pribadi masyarakat } \\
\text { terhadap orang asing }\end{array}$ & 373 & $79,36 \%$ & Setuju \\
\hline & $\begin{array}{l}\text { Pembangunan jalan lingkungan } \\
\text { yang memadai }\end{array}$ & 470 & $100 \%$ & Sangat setuju \\
\hline & $\begin{array}{l}\text { Ketersediaan angkutan wisatawan } \\
\text { di dalam desa }\end{array}$ & 377 & $80,21 \%$ & Sangat setuju \\
\hline & $\begin{array}{l}\text { Pembukaan desa untuk kedatangan } \\
\text { investor/ pemodal }\end{array}$ & 242 & $51,48 \%$ & Cukup setuju \\
\hline
\end{tabular}

konji, borok-borok yang terbuat dari kantung semar dan beras ketan, juga galamai.

Secara umum masyarakat Koto Sentajo mau menerima kedatangan orang asing di wilayahnya. Orang asing yang dimaksud bisa berupa wisatawan domestik di luar 4 persukuannya maupun wisatawan luar negeri. Dalam hal ini peneliti condong mengikuti terminologi orang asing dalam perspektif umum masyarakat lokal untuk menyebut semua orang di luar kelompok sukunya. Hanya saja, terdapat batasan-batasan yang wajib dilaksanakan wisatawan selama berada di dalam desa, yaitu menjaga sopan santun, tidak berbicara kasar, dan berhati bersih.

Untuk aksesibilitas fisik, desa ini sudah dilengkapi dengan jalan rabat beton yang menghubungkan satu rumah godang dengan rumah godang yang lain. Hanya saja, lebarnya cukup menampung satu mobil saja, sehingga kendaraan roda empat tidak boleh memasuki kawasan permukiman. Angkutan kendaraan lain belum tersedia, sehingga wisatawan harus berjalan kaki bila ingin mneyusuri desa. Alternatif yang ditawarkan berupa jenis kendaraan tidak bermotor atau kereta yang ditarik sapi/kerbau.

Adapun untuk indikator masuknya investor asing ditentang warga, sebab mereka memiliki ikatan adat yang kuat terhadap tanah ulayatnya. Investor boleh membangun usaha akan tetapi harus berada di luar dusun. Secara khusus, model ini sangat mendukung upaya pembangunan pariwisata berbasis kerakayatan, di mana masyarakat lokal yang harus menjadi penggerak utama ekonomi di destinasi wisata. 


\section{SIMPULAN}

Berdasarkan hasil dan pembahasan yang dilakukan sebelumnya, maka kesimpulan dalam penelitian dapat diajukan sebagai berikut. Penghitungan persepsi masyarakat lokal terhadap variabel-variabel dalam pengembangan desa wisata yang meliputi wisatawan, atraksi, amenitas, dan aksesibilitas desa dengan menggunakan skala likert menunjukkan hasil yang beragam. Variabel wisatawan dengan indikator masyarakat memperhatikan daerah asal wisatawan sebesar $59,15 \%$, memperhatikan warna kulit sebagai pertimbangan $44,04 \%$, budaya asal yang dibawa $87,02 \%$, dan agama yang dianut $52,12 \%$. Untuk varibel atraksi, masyarakat lokal memandang bahwa wisatawan boleh menyaksikan budaya sehari-hari 98,08\%, pacu jalur dan adat lainnya terbuka untuk wisatawan $100 \%$, randai boleh dimainkan setiap diperlukan $100 \%$, dan bangunan bersejarah boleh dimasuki wisatawan $100 \%$. Variabel amenitas dinilai dari persepsi masyarakat lokal terhadap dibukanya kedai makananminuman $97,97 \%$, kebersihan lingkungan $100 \%$, penggunaan rumah godangs ebagai homestay $90,63 \%$, dan ragam masakan tradisional boleh dinikmati secara umum $100 \%$. Terakhir adalah variabel aksesibilitas, masyarakat terbuka terhadap oranga sing $79,36 \%$, pembangunan jalan desa $100 \%$, angkutan dalam desa $80,21 \%$, dan masuknya investor $51,48 \%$. Artinya masyarakat telah bersikap terbuka, namun menutup diri dalam beberapa hal terkait adat, kepemilikan lahan, norma, dan agama Islam yang dianutnya.

Penelitian ini selanjutnya menyarankan langkah-langkah konkret sebagai lanjutan hasil penelitian, meliputi: 1).Memperbanyak pelatihan bidang kepariwisataan untuk mempersiapkan sumber daya manusia yang handal, seperti pemandu wisata, pembuat souvenir, serta pengelola desa wisata; 2) membangun koordinasi yang baik lintas sektor sehingga kesan pembangunan desa wisata cenderung terlihat stagnan, baik dari PUPR, Dinas Pariwisata, Balai Pelestarian Purbakala dan Cagar Budaya, Dinas Kesehatan daerah maupun pemerintahan desa dan pengurus kepenghuluan Sentajo; dan 3) perumusan tata kelola desa wisata yang baik melalui kajian-kajian ilmiah dan program pengabdian masyarakat.

\section{DAFTAR RUJUKAN}

Asrori, M. 2009. Psikologi Pembelajaran. Bandung: CV. Wacana Prima.

Bertram, D. "Likert Scale". Diakses dari http:// www.rolahengki.com/2013

Biro Pusat Statistik. 2017. Sentajo Raya dalam Angka 2017. BPS.

Dermatoto, A. 2009. Pembangunan Pariwisata Berbasis Masyarakat. Surakarta: Sebelas Maret University Press

Ghozali, I. 2011. Structural Equation Modelling, Metode Alternatif dengan Partial Least Structural (PLS). Semarang: Undip.

Gunn, C. A. 1993. Tourism Planning: Basic Concepts Cases (3th ed.). Washington D.C: Taylor \& Francis.

Handoko, T.Y. 2018. "Kunjungan Wisman Meleset,Pencapaian Devisa di Atas Target", dalam https://travel.tempo.co tanggal 20 Desember 2018.

Murphy, P.E. 1985. Tourism: A Community Approach. London: Methuen.

Nazir, M. 2011. Metode Penelitian. Bogor: Ghalai Indonesia.

Nuryanti, W. 1993. "Concept, Perpective, and Challenges", dalam Laporan Konferensi Internasional Mengenai Pariwisata Budaya. Yogyakarta: Gadjah Mada University Press.

Nuryanti, W. 1999. Heritage, Tourism adn Local Community. Yogyakarta: Gadjah Mada University Press.

Pemerintah Republik Indonesia. 2009. UndangUndang No. 10 tahun 2009 tentang Kepariwisataan Indonesia. Kementerian Pariwisata dan Ekonomi Kreatif.

Robbins, S. P. 1996. Perilaku Organisasi: Konsep, Kontroversi, Aplikasi. Jakarta: PT. Prenhalindo.

Slameto. 2010. Belajar dan Faktor-Faktor yang Mempengaruhinya. Jakarta; Rineka Cipta.

Suansri, P. 2003. Community Tourism Handbook. Thailand: REST Project.

Sugiono. 2012. Metode Penelitian Kuantitatif, Kualitatif, dan R\&D. Bandung: Penerbit Alfabeta. 
46 Jurnal Kebijakan Publik, Volume 11, Nomor 1, Maret 2020, hlm. 1-58

Toha, M. 2003. Perilaku Organisasi: Konsep Dasar dan Aplikasinya. Jakarta: Grafindo Persada.
Walgito, B. 1989. Pengantar Psikologi Umum. Surabaya: Bina Ilmu. 